\title{
Pendidikan Kebangsaan Dalam Perspektif Pendidikan Islam
}

\author{
Johari Rugani \\ Universitas Cokroaminoto Makassar \\ joharirugani@cokrominoto.ac.id \\ Didin Hafidhuddin \\ Universitas Ibn Khaldun Bogor \\ Andian Husaini \\ Universitas Ibn Khaldun Bogor
}

\begin{abstract}
ABSTRAK
Tujuan pendidikan kebangsaan untuk menciptakan generasi bangsa yang berwatak dan menciptakan peradaban bangsa yang bermartabat, yang menempatkan kepentingan bangsa dan negara di atas kepentingan individual dan kelompok. Namun hingga kini, lemahnya pendidikan nilai-nilai kebangsaan karena lemahnya transformasi pembelajaran kebangsaan dalam lingkungan pendidikan formal, non formal termasuk keluarga yang berimplikasi pada globalisasi dan berdampak pada pelemahan nasionalisme. Tetapi, perspektif negatif ini tidak mempengaruhi Universitas Cokroaminoto untuk melakukan transformasi nilai-nilai pendidikan kebangsaan disemua kalangan cipitas akademik. Justru itu, kajian ini penting untuk memahami kerangka pemikiran H.O.S. Cokroaminoto terhadap pendidikan kebangsaan dalam perspektif Pendidikan Islam. Penelitian ini merupakan penelitian kajian pustakan dengan metode kualitatif deskriftif. Kajian dimulai dengan pengumpulan data-data dokumen berupa buku, jurnal, blong dan hasil-hasil penelitian lainnya. Analisis data dokumen dilakukan dengan analisis konten, seterusnya data dokumen yang telah dikumpulkan dianalisis secara interaptif untuk menghasilkan kerangka teori. Melalui pendekatan teori fungsional, hasil penelitian menemukan sebagaimana kerangka pemikiran H.O.S Cokroaminoto tentang pendidikan kebangsaan berbasis Islam dapat meretas keraguan, membentuk jiwa sosialisme, memperkuat nasionalisme dan memperkokoh kepemimpin serta membentuk ekonomi interfenersif. Justru itu, Universitas Cokroaminoto harus lebih mendorong pada aspek pengembangan pendidikan kebangsaan yang berdialogi sosialisme islamisme.
\end{abstract}

Kata Kunci : Pendidikan, Kebangsaan dan Islamisme

\section{INTRODUCTION}

Pendidikan Islam sebagai bagian dari sistem sosial yang dipahami sebagai aktivitas bimbingan yang disengaja untuk mencapai kepribadian muslim pada operasionalisasinya melibatkan berbagai komponen yang berkaitan erat satu sama lainnya. Oleh karena itu, Mappanganro mengemukakan pendidikan Islam pada dasarnya adalah sebuah sistem, dimana proses pendidikan Islam dipahami sebagai interaksi antara komponen yang satu dengan yang lainnya guna mencapai tujuan pendidikan Islam (Mappanganro, 1996). Pada hakikatnya, pendidikan Islam adalah suatu proses yang 
berlangsung secara kontinyu dan berkesinambungan. Pada awal abad ke-19 di Indonesia muncul gerakan nasional khususnya dari kalangan Islam yang mencoba menghimpun kekuatan untuk melawan pemerintah kolonial Belanda, mulai dari Budi Utomo, Sarekat Dagang Islam yang kemudian berkembang menjadi Serikat Islam dan gerakan-gerakan lainnya (Amelz, 1952). Dari pergerakan itulah muncul para tokoh intelektual terkemuka dari kalangan Islam, salah satu tokoh yang terkenal adalah Oemar Said Cokroaminoto. Ia merupakan seorang tokoh yang memiliki peranan penting dalam perkembangan organisasi Sarekat Islam. Sebagai Intelektual Islam tentunya banyak pemikiran-pemikiran yang ia lahirkan. Salah satu gagasannya adalah tentang konsep Sosialisme Islam. Amelz mengatakan bahwa berawal dari penjajahan Belanda yang mengeksploitasi Indonesia dari berbagai bidang mulai perdagangan, sosial-politik, pendidikan dan berbagai bidang lainnya. Muncul Sarekat Islam (kelanjutan dari Sarekat Dagang Islam) sebagai pergerakan yang mengusung kemerdekaan dengan berbasiskan Islam.

Namun dalam perjalanan sejarah dari masa ke masa sebagaimana pendapat Ajib Rosidi yang menyatakan bahwa Cokroaminoto dalam sejarahnya sampai sekarang masih sangat kurang mendapatkan sorotan perhatian dan publikasi secara nasional. Bahkan terjadi persepsi dengan menganggapnya bahwa H.O.S. Cokroaminoto hanya sebatas tokoh Partai Syarikat Islam Indonesia (PSII). Pada hal perjalanan sejarahnya beliau merupakan seorang tokoh yang banyak berjasa dengan ide dan konsep terhadap pembangunan bangsa ini. Hal tersebut terbukti dimana H.O.S. Cokroaminoto merupakan peletak dasar pemikiran tentang berbagai persoalan nasional termasuk pendidikan kebangsaan. Banyak konsep dan kerangka pikir yang lahir serta muncul diberbagai individu yang mereka tidak sadari, ternyata semuanya itu merupakan konsep dasar dari pemikiran Cokroaminoto (Rosidi dan Ajib, 1973).

\section{LITERATURE REVIEW}

Herdi Sahrasad mengatakan bahwa dalam sebuah artikel yang ditulis oleh Humaidi tentang Potret Pemikiran Nasionalisme Islam Indonesia, terdapat perubahan pola pikir dalam diri Cokroaminoto (Herdi dan Sahrasad, 2000). Oleh karena itu Humaidi menggunakan istilah "Cokro Muda" dan "Cokro Tua". "Cokro Muda" adalah Cokroaminoto yang bersemangat, dan melihat Islam sebagai alat untuk memperjuangkan nasionalisme dan memperjuangkan persatuan nasional. Sementara "Cokro Tua" adalah Cokroaminoto yang mulai berfikir secara dikotomis yaitu membedakan Islam dan komunisme sebagai bagian terpisah dalam menafsirkan nasionalisme. 
H.O.S. Cokroaminoto menerangkan tentang 4 konsep Islam yaitu: (1) Islam itu aslama maknanya taat kepada Allah, utusan-Nya, dan pada pemerintah. Seperti yang tercantum dalam Q.S An Nisa ayat 59. (2) Islam itu salimun artinya selamat, maksudnya jika orang Islam menjalankan perintah agama niscaya ia akan mendapatkan keselamatan dunia dan akhirat. (3) Islam berasal dari kata salmi yang artinya rukun, maksudnya orang orang yang berpegang menumbuhkan persaudaraan yang benar-benar harus dilaksanakan antara umat Islam di Negara manapun juga dan (4) Islam dengan mekanisme zakat memberikan pelajaran tentang pemenuhan kebutuhan secara merata. Untuk mewujudkan sosialisme ada tiga dasar yang harus dilaksanakan yaitu: 1) Membangun perasaan rela mengorbankan kepentingan pribadi demi kepentingan umum. 2) Membagi kekayaan sama rata dalam dunia Islam dengan mekanisme zakat, dan 3) Menuntun perasaan orang supaya tidak menganggap kemiskinan itu suatu penghinaan karena itu lebih baik dari kejahatan. Sebagaimana pandangan Haq, (2011) bahwa dinamisasi perjuangan HOS Cokroaminoto semakin jelas dan lebih mematangkan nilai-nilai kebangsaan Islam Indonesia melalui gerakan pemantang intelektual yang dibingkai dengan gerakan konsep pendidikan kebangsaan, untuk turut serta dalam mengantarkan bangsa Indonesia ke pintu kemerdekaannya. Oleh karena Pentingnya pendidikan sebagai wadah pembentukan jati diri individu untuk kepentingan bangsa sebagaimana pandangan Natsir, (1973) bahwa pendidikan selain sebagai salah satu kebutuhan hak asasi manusia juga sebagai pembentukan manusia dan jati diri manusia yang sebenarnya. Oleh karena itu, maju mundurnya suatu kaum serta rugi dan beruntungnya sangat ditentukan oleh sebahagian besar pada konteks pendidikan yang berlaku di kalangan mereka sendiri. Justru itu, pendidikan perlu didesain sebagaimana pendapat H.O.S. Cokroaminoto bahwa desain pendidikan dengan berlandaskan pada kepentingan bangsa akan membentuk generasi yang memiliki jiwa rela berkorban akan ibu pertiwi.

\section{METHODOLOGY}

Menurut Denzin dan Lincoln. (2009) dan Bogdan dan Biklen, (2006) menyatakan bahawa desain penelitian merupakan hal penting dalam sebuah penelitian kerana desain kajian adalah uraian mengenai proses pengkajian yang akan dijalankan peneliti dengan tujuan untuk menjawab rumusan masalah. Oleh karena itu, desain penelitian yang digunakan dalam penelitian ini adalah desain penelitian kualitatif dengan pendekatan studi kasus (penelitian sejarah) yang prosesnya berfokus pada masa lampau. Hal ini berarti bahwa penelitian ini melakukan analisis terhadap keadaan dan perkembangan serta 
pengalaman pada masa lalu. Sehingga, perlu mendapat pertimbangan secara hati-hati dan teliti terutama bukti dan validitas sumber sejarah dan interprestasi dari keterangan yang diperoleh. Dengan demikian, bentuk penyusunan yang dilakukan dengan menggunakan metode historis atau sejarah. Pengunaan pendekatan studi kasus pada penelitian ini kerana dapat memberikan informasi terhadap peristiwa tentang individu, sosial politik dan organisasi yang sifatnya nyata terhadap konteks penelitian (Daymon, C., dan Holloway, I, 2008). Untuk lebih jelasnya penelitian ini merupakan penelitian kajian pustakan dengan metode kualitatif deskriftif. Kajian dimulai dengan pengumpulan datadata dokumen berupa buku, jurnal, blong dan hasil-hasil penelitian lainnya. Analisis data dokumen dilakukan dengan analisis konten, seterusnya data dokumen yang telah dikumpulkan dianalisis secara interaptif untuk menghasilkan kerangka teori tentang pemikiran H.O.S. Cokroaminoto tentang pendidikan kebangsaan dalam perspektif pendidikan islam.

\section{RESEARCH FINDINGS}

\section{Pendidikan Kebangsaan Bersandarkan Islam Meretas Keraguan}

Islam adalah sebenar-benarnya satu agama yang bersifat demokratis dan telah menetapkan beberapa banyak hukum yang bersifat sosialistik bagi orang-orang yang memeluknya (Nugroho dan Anjar, 2013). Islam merupakan agama yang tidak membedakan status sosial, selalu berpihak pada kebenaran, justru itu H.O.S. Cokroaminoto dalam pergerakannya berkenaan sosialisme islam tidak pernah ragu terhadap perjuangannya dalam membela masyarakat pribumi yang tertindas.

Penguatan nilai-nilai kebangsaan yang berasaskan islam selain menghilangkan permusuhan yang berasal dari turun temurun yang sudah berabad-abad lamanya juga dapat membentuk persaudaraan islam sampai pada tingkat yang tertinggi, sebagaimana gerakan penyatuan aliran agama yang dilakukan oleh H.O.S. Cokroaminoto yang berlandaskan pada paham Islamisme, walaupun alirin-aliran tersebut memiliki banyak perbedaan akan tetapi perbedaan tersebut tidak menjadi suatu problem karena tujuan mereka sama yaitu pembelaan terhadap masyarakat tertindas, perjuangan, dan Islamisme (Mulawarman A. D, 2006). Selain itu juga dijelaskan sebagai bukti bahwa sepeninggalnya Nabi Muhammad saw, pimpinan Negara madinah tidak diberikan kepada keluarganya yang terdekat dan tercinta, tetapi diberikan kepada salah seorang sahabatnya. Islam telah menghapuskan perbedaan dalam suatu bangsa baik perbedaan warna kulit dan semuanya sama dihadapan Tuhan. Ini artinya bahwa kunci dalam membangun nilai-nilai 
kebangsaan mesti pendidikan kebangsaan yang berideologi islamisme. Dengan ideology pendidikan kebangsaan islamisme akan melahirkan generasi yang memiliki kepercayaan diri, etos kerja yang lebih tinggi dan akan meretas semua keraguan, perbedaan dalam diri individu.

Dalam masyarakat dengan pahan Islam-Tauhid-Allah dan rasulnya sebagai media pergerakan untuk menarik berbagai golongan dan strata sosial, mulai dari kalangan seperti nasionalisme, kedaerahan baik arus bawa maupun arus atas (Nugroho, Anjar, 2013). Konsep pergerakan Tauhidi H.O.S. Cokroaminoto, ummat benar-benar satu, tidak dibedakan lagi karena kedudukan sosial, jenis kelamin, dan warna kulit. Dan itu adalah sama dengan masyarakat komunis. Masyarakat Tauhidi ini, adalah tingkat yang lebih tinggi dari masyarakat yang dijanjikan Tuhan: "Akan menjadikan kaum mustadhafin menjadi pemimpin di bumi dan mewarisi bumi." Untuk bisa membuminya isi surat $\mathrm{Al}$ Qashash ayat 5-6 sebagai langkah awal menuju masyarakat Tauhidi (ummat yang satu), maka kaum mustadhafin harus mengamalkan Surat Al Ra'du ayat 11, yang berbunyi: "Sesungguhnya Allah tiada mengubah keadaan suatu kaum, kecuali jika mereka mengubah keadaan diri mereka. Inilah yang menjadi konsep gerakan keberanian H.O.S. Cokroaminoto yang selalu berlandaskan pada Al Qur'an.

\section{Pendidikan Kebangsaan Bersandarkan Islam Membentuk Jiwa Sosialisme}

H.O.S. Tjokroaminoto merupakan seorang tokoh besar Islam dan sosialisme yang sangat disegani pada masa perebutan kemerdekaan Indonesia. Dalam buku Islam dan Sosialisme, Tjokroaminoto menyampaikan ide-idenya mengenai paham sosialisme yang dapat dibentuk dari esensi ajaran Islam. Menurutnya, sosialisme menghendaki suatu cara hidup yang menyadari bahwa setiap individu memikul tanggung jawab terhadap manusia-manusia lain (Wibisono, Jusuf, 1950). H.O.S. Tjokroaminoto memberikan penekanan pada sosialisme Islam yang berbeda dengan sosialisme yang bersumber pada materialisme, seperti misalnya Marxisme. Menurutnya sosialisme yang berasal dari ajaran Islam memiliki keunggulan-keunggulan tersendiri dan lebih cocok untuk dijalani oleh kaum muslim daripada sosialisme materialis (Nugroho, Anjar, 2013). Untuk mendukung argumen itu, ia memberikan banyak sekali contoh hadis, ayat alQuran, dan berbagai kisah yang menyiratkan kuatnya nilai-nilai sosialistis dalam ajaran Islam. Di antara contoh-contoh yang diberikannya adalah mengenai persaudaraan dalam Islam, sedekah, persamaan dan kesetaraan derajat, kesederhanaan, serta keadilan ekonomi bagi masyarakat. Pemikiran inilah yang menjadi karakter dan cirri khas bagi H.O.S. Tjokroaminoto yang harus ditanamkan bagi setiap generasi di berbagai lembaga 
pendidikan termasuk lingkungan keluarga, tujuannya adalah untuk lebih memantapkan nilai-nilai kebangsaan.

Meskipun berusaha membedakan sosialisme yang ia maksud dengan sosialisme materialis dan berusaha menunjukkan keunggulan-keunggulan ajaran Islam, ia juga menekankan bahwa pemikirannya tidak bermaksud untuk mendiskreditkan pemikiranpemikiran guru sosialis Barat seperti Karl Marx dan Friedrich Engels tentang perbaikan kaum miskin di negeri-negeri Barat. Meski demikian, ia membenarkan bahwa ajaran Islam, seperti halnya banyak paham sosialisme, sangat bertentangan dengan sistem kapitalisme. Menurutnya, kapitalisme berawal dari benih pemakanan riba' (bunga), dan Islam dengan keras melarang praktek riba, dengan kata lain memerintahkan untuk mencegah munculnya kapitalisme dan berusaha memeranginya. Ajaran Islam yang mengarah pada paham tersebut, H.O.S. Tjokroaminoto menegaskan bahwa sikap demikian akan meruntuhkan sikap sosialisme dan runtuhnya akidah serta moral bangsa karena akan mengarah pada kapitalisme dan korupsi (Yusuf, 1987).

Melalui ide-ide dan konsep pergerakan H.O.S. Cokroaminoto sebagian orang melihat H.O.S. Cokroaminoto sebagai seorang cendekiawan Islam. Hal ini mungkin karena memang H.O.S. Cokroaminoto memiliki pandangan yang berorientasi jauh ke depan tentang sistem kenegaraan yang berlandaskan akan nilai-nilai Islam. Salah satu pemikiran yang sangat menonjol dari seorang H.O.S. Cokroaminoto adalah kecenderungan keinginannya dalam menata republik ini dengan sistem perwakilan yang dipilih yang mirip dengan trias politika.

\section{Pendidikan Kebangsaan Bersandarkan Islam Memperkuat Nasionalisme}

Tumbuh dan berkembangnya nasionalisme tidak lepas dari nilai-nilai kebangsaan sehingga telah melahirkan banyak negara dan bangsa merdeka di seluruh dunia. Hal ini antara lain, disebabkan karena nasionalisme telah memainkan peranan yang sangat penting dan positif didalam menopang tumbuhnya persatuan dan kesatuan, serta nilainilai demokrasi, yang oleh karena itu negara bangsa yang bersangkutan dapat melaksanakan pembangunan nasional sebagai upaya peningkatan kemakmuran dan peningkatan kualitas pendidikan rakyat. Perkembangan nasionalisme yang mengarah pada upaya untuk melakukan pergerakan nasional guna melawan penjajah tidak bisa lepas dari peran berbagai golongan yang ada dalam masyarakat, seperti golongan terpelajar, kaum cendekiawan, golongan profesional, dan golongan pers (Parekh, 2008). Gerakan nasionalisme yang berlandaskan Islam yang disuarakan H.O.S. Cokrominoto kecenderungannya semata-mata mengarah pada perlawanan pada kaum penjajah bukan 
pada aspek perang wanita terhadap hak pendidikan dan kepemimpinan sebagaimana dalam buku (Mulawarman A. D, 2006).

Gerakan penanaman nilai-nilai kebangsaan menuju kekuatan nasionalisme sangat ditentukan oleh tranformasi golongan orang-orang terpelajar dalam masyarakat. Melalui golongan terpelajar yang berasal dari daerah yang berbeda tetapi mereka merasa senasib sepenanggungan untuk mengatasi bersama adanya penjajahan, kapitalisme, kemerosotan moral, penetrasi budaya, dan kemiskinan bangsa. Hingga akhirnya mereka membentuk perkumpulan yang selanjutnya menjadi Organisasi Pergerakan Nasional. Mereka membentuk organisasi-organisasi modern yang berwawasan nasional. Mereka berusaha menanamkan pentingnya persatuan dan kesatuan bangsa, menanamkan rasa nasionalisme, menanamkan semangat untuk memprioritaskan segalanya demi kepentingan nasional daripada kepentingan pribadi melalui organisasi tersebut. Selanjutnya melalui organisasi pergerakan nasional tersebut mereka melakukan gerakan untuk melawan penjajahan yang selanjutnya membawa Indonesia pada kemerdekaan.

Selain peranan golongan terpelajar dalam membangkitkan nilai-nilai nasionalisme masyarakat, peranan ini juga sangat ditentukan oleh golongan profesional seperti guru, dan dokter. Keanggotaan golongan ini hanya terbatas pada orang seprofesinya. Golongan profesional ini lebih banyak ada dan mengembangkan profesinya didaerah perkotaan. Golongan profesional pada masa kolonial memiliki hubungan yang dekat dengan rakyat, sehingga mereka dapat mengetahui keberadaan rakyat Indonesia pada saat itu. Sehingga golongan ini dapat menggerakkan kekuatan rakyat untuk menentang kekuasaan pemerintah kolonial Belanda. Jadi gerakan profesional merupakan ujung tombak perjuangan bangsa Indonesia untuk mencapai kemerdekaannya dan berjuang memajukan bangsa Indonesia dari keterbelakangan (Suwirta, Adam, Arlin, 2012). Guru memberikan pendidikan dan pengajaran kepada generasi penerus bangsa melalui lembaga-lembaga pendidikan yang ada baik itu sekolah yang didirikan oleh pemerintah kolonial maupun sekolah yang didirikan oleh tokoh-tokoh bangsa Indonesia seperti H.O.S. Cokrominoto bersama istrinya Suharmisi.

\section{Pendidikan Kebangsaan Bersandarkan Islam Memperkokoh Kepemimpinan}

H.O.S. Cokroaminoto selain mendapat gelar sebagai guru bangsa, juga dikenal sebagai pemimpin yang demokratis (Arifin dan Suarif, 1999). Sebagai seorang pemimpin dari organisasi SI yang memiliki massa terbesar pada masa itu, penyebaran pikiranpikiran H.O.S. Cokroaminoto juga mengalami perkembangan ke berbagai kalangan 
generasi. Diberbagai generasi muda yang progresif terbius dengan pidato-pidato H.O.S. Cokroaminoto. Sikap kepemimpinan H.O.S. Cokroaminoto yang tegas, sosial, pemberani dan terbuka terhadap berbagai macam ideologi yang membuat banyak orang yang segang sama beliau. Terbukti sikap terbuka H.O.S. Cokroaminoto dengan dijadikannya rumah beliau sebagai wadah pertemuan dengan berbagai paham tampak kekhawatiran sedikitpun dampak yang akan terjadi (Pradana, Rintahani Johan, 2014). Berkat keseriusan H.O.S. Cokroaminoto dalam membentuk generasi melalui penanaman nilai-nilai kebangsaan yang mengarah pada pembentukan nasionalisme Islam, H.O.S. Cokroaminoto banyak mencetak tokoh-tokoh besar diantaranya Tan Malaka, Alimin, Kartoswirjo, Bung Karno, dll. Hal yang mungkin kita patut untuk acungi jempol adalah sikap H.O.S. Cokroaminoto yang sama sekali tidak pernah memaksakan keyakinannya, yaitu ideologi keislaman untuk dituruti oleh para murid-muridnya itu. Dia adalah seorang guru yang sangat bijaksana yang membiarkan para anak didiknya untuk berkiprah diberbagai bidang yang mereka senangi dan sesuai dengan naluri mereka masing-masing sebagai sebuah titah Tuhan yang telah diberikan-Nya.

Kebasaran hatinya dan keluasan pemiikirannya telah membawa sebuah garis lurus dalam seluruh sejarah bangsa Indonesia. Meskipun pada akhirnya sejarah tidak banyak menuliskan namanya, tetapi penulis yakin bahwa tinta untuk H.O.S. Cokroaminoto tidak harus semuanya ditumpahkan ke atas kertas, tetapi tinta untuk H.O.S. Cokroaminoto sudah sangat mulia untuk melukis pemiikiran dan nuraninya para pemikir besar pada zaman setelahnya, mungkin sampai waktu yang tidak ditentukan. Perjuangan HOS Tjokroaminoto semasa zaman penjajahan sebagai figur yang memiliki pengaruh besar bagi kemajuan bangsa, termasuk sosok dibalik munculnya pemimpin-pemimpin besar bangsa seperti Soekarno, Semaoen, Musso dan Kartosoewirjo. Di kala menjadi tokoh pendiri Sarekat Islam, organisasi pertama yang hadir untuk memperjuangkan persamaan hak dan martabat masyarakat pribumi di tengah penjajahan Hindia Belanda (Darussalam, et al, 2013).

\section{CONCLUSION}

Kerangka pemikirin H.O.S Cokrominoto tentang pendidikan kebangsaan berbasis pada Islam karena Islam merupakan agama yang tidak membedakan status sosial dan selalu berpihak pada kebenaran. Justru itu, H.O.S. Cokroaminoto dalam pergerakannya berkenaan sosialisme islam tidak pernah ragu terhadap perjuangannya dalam membela masyarakat pribumi yang tertindas, ide-idenya mengenai paham sosialisme yang dapat 
dibentuk dari esensi ajaran Islam. Menurutnya, sosialisme islam menghendaki suatu cara hidup yang menyadari bahwa setiap individu memikul tanggung jawab terhadap manusiamanusia lainnya. Ini Artinya tumbuh dan berkembangnya nasionalisme tidak lepas dari nilai-nilai kebangsaan sehingga telah melahirkan banyak negara dan bangsa merdeka di seluruh dunia. Hal ini antara lain, disebabkan karena nasionalisme telah memainkan peranan yang sangat penting dan positif didalam menopang tumbuhnya persatuan dan kesatuan, serta nilai-nilai demokrasi, yang oleh karena itu negara bangsa yang bersangkutan dapat melaksanakan pembangunan nasional sebagai upaya peningkatan kemakmuran dan peningkatan kualitas pendidikan rakyat. Oleh karena itu, pencerminan sikap kepemimpinan H.O.S. Cokroaminoto yang tegas, sosial, pemberani dan terbuka terhadap berbagai macam ideologi yang membuat banyak orang yang segang sama beliau mesti menjadi acuan hidap dalam proses sosial. Keseriusan dan keiklasan H.O.S. Cokroaminoto dalam membentuk generasi melalui penanaman nilai-nilai kebangsaan yang mengarah pada pembentukan nasionalisme Islam, H.O.S. Cokroaminoto banyak mencetak tokoh-tokoh besar diantaranya, Alimin, Kartoswirjo, Bung Karno. Hal yang mungkin kita patut jadikan cermin hidup adalah sikap H.O.S. Cokroaminoto yang sama sekali tidak pernah memaksakan keyakinannya, seperti ideologi keislaman untuk diikuti oleh para murid-muridnya. Dari hal tersebut tergambar sosok seorang guru yang sangat bijaksana yang membiarkan para anak didiknya untuk berkiprah diberbagai bidang yang mereka minati dan sesuai dengan naluri mereka masing-masing sebagai sebuah titah ideologi keTuhan yang telah diberikan-Nya.

\section{REFERENCES}

Amelz, (1952). HOS Tjokroaminoto Hidup dan Perjuangannya. Jilid I, Jakarta: Bulan bintang.

Ali, Mukti, (1975). Meningkatkan Penelitian Ilmu-Ilmu Agama, Yogyakarta: al-Jamieeah IAIN Sunan Kalijogo.

Arifin, Fx Suarif, (1999). Petisi Soetardjo: Upaya Damai Meraih Kemerdekaan. Atma nan Jaya: majalah ilmiah Universitas Katolik Indonesia Atma Jaya, 12.1-3: 111.

Amin, (1995). Cokroaminoto Rekonstruksi Pemikiran dan Perjuangannya, Yogyakarta: Cokroaminoto University Press.

Aria, Y.; Dwi, Rhoma, (2015). The Grand Old Man Indonesia: Pers dan Nasionalisme.

Bogdan, R. C. \&. Biklen, S. K. (2006). Qualitative research for education: An introduction to theories and methods. 
Daymon, C., dan Holloway, I. (2008). Metode-Metode Riset Kualitatif: dalam Public Relations dan Marketing Communications. Yagyakarta: PT. Bentang Pustaka.

Darussalam, et al. (2013). Sosialisme Islam (Tela'ah Pemikiran Hos Tjokroaminoto). $\mathrm{PhD}$ Thesis. UIN Sunan Kalijaga.

Denzin, N. K., dan Lincoln, Y. S. (2009). Pendahuluan Memasuki Bidang Penelitian Kualitatif (Dariyatno, B. S. Fata, Abi \& J. Rinaldi, Trans.). In N. K. Denzin \& Y. S. Lincoln (Eds.), Handbook of Qualitative Research (2 ${ }^{\text {nd }}$ ed.,2009.pp. 1-25). Yogyakarta: Pustaka Pelajar.

Haq, Hamka, (2011). Pancasila 1 Juni dan Syariat Islam, Jakarta: PT. Wahana Semesta Intermedia.

Herdi Sahrasad, (2000). HOS Cokroaminoto, Sosialisme di dalam Islam, dikutip dari Islam, Sosialisme dan Komunisme. Jakarta: Madani Press.

Kirom, Sazalil, et al. (2013). Buruh Dan Kekuasaan: Dinamika Perkembangan Gerakan Serikat Pekerja Di Indonesia (Masa Kolonial-Orde Lama). Jurnal Mahasiswa Teknologi Pendidikan, 1.1.

Mappanganro, (1996). Implementasi Pendidikan Islam di Sekolah, Ujung Pandang: Yayasan Ahkam.

Mulawarman A. D. (2006). Jang Oetama Jejak dan Perjuangan H.O.S. Tjokroaminoto. Yagyakarta: Galang Pustaka; 21-33

Natsir, M, (1973). Kapita Selekta, Jakarta: Bulan Bintang Hal 77

Nugroho, Anjar. (2013) Wacana Islam dan Negara Era Pra-Kemerdekaan: Pergulatan Ideologis Kelompok Islam dan Nasionalis Sekuler. Jurnal Afkaruna, 9.2.

Pradana, Rintahani Johan, (2014). Strategi Pendidikan Tjokroaminoto dalam Rumah Kost Soeharsikin Surabaya (1912-1922). SKRIPSI Jurusan Sejarah-Fakultas Ilmu Sosial UM.

Rosidi, Ajib, (1973). HOS. Cokroaminoto, Yogyakarta: Mimbar.

Suwirta, Andi; Adam, Arlin. (2012). Membincang Kembali Masalah Etnisitas, Nasionalitas, dan Integrasi Nasional di Indonesia. ATIKAN, 2(2).

Wibisono, Jusuf. (1950). Islam dan sosialisme. Pustaka Islam.

Yusuf, Moh. (1987). Sarikat Islam Dalam Pergerakan Nasional Indonesia: Suatu Tinjauan Historis. PhD Thesis. UIN Sunan Ampel Surabaya. 